FOCAL PROBLEMS IN GEOGRAPHY

POPULATION AND RESOURCES 


\section{Population and Resources}

H. ROBINSON

Macmillan Education 
ISBN 978-0-333-19127-9 ISBN 978-1-349-16545-2 (eBook)

DOI 10.1007/978-1-349-16545-2

(C) Harry Robinson 1981

Softcover reprint of the hardcover 1st edition 1981

All rights reserved. For information, write:

St. Martin's Press, Inc., 175 Fifth Avenue, New York, NY 10010

First published in the United States of America in 1982

ISBN 978-0-312-63120-8

\section{Library of Congress Cataloging in Publication Data}

Robinson, Harry, 1915-

Population and resources.

Bibliography: $p$.

Includes index.

1. Population. 2. Population-Economic aspects.

I. Title.

HB871.R58 $1981 \quad 304.6 \quad 81-8760$

ISBN 978-0-312-63120-8 AACR2 


\section{Contents}

List of Figures vii

List of Tables viii

Preface ix

Acknowledgements $\quad$ x

Introduction

Part One: The Historical Perspective

1 The Growth of World Population 7

2 World Population Movements and Distribution 21

3 Resources: Their Nature and Distribution 34

4 Population-Resource Relationships 53

Part Two: The Developed World

5 Population Problems and Movements 73

6 Diagnostic Characteristics and Problems 97

Part Three: The Developing World

7 Population Growth in the Third World 121

8 Social Problems 144

9 Economic Problems 166

10 Political Problems 191

Part Four: Future Trends, Possibilities and Solutions

11 People, Land and Food 203

12 Resource Consumption 222

13 Possible Solutions 234

14 Conclusion 246 
Bibliography

References 262

Index

271 


\section{List of Figures}

1.1 Population pyramids

1.2 Types of population structure

1.3 World population growth

1.4 Projected population growth by area

2.1 World distribution of population

2.2 Demographic transition

3.1 The world's mountainous areas

3.2 The world's arid areas

3.3 The world's total negative areas

3.4 Lifetimes of estimated recoverable reserves of mineral resources

4.1 Generalised population/resource regions of the world

5.1 Population growth: world, developing and developed areas

5.2 Population change in Great Britain 1951-61

5.3 Population movements in Europe

6.1 World literacy

6.2 World per capita income, circa 1973

6.3 Annual growth rate in food production

6.4 Regional imbalance in Europe

7.1 Estimated birth and death rates, 1770-1970

7.2 Population pyramid, Type 2

7.3 Dependency loads

7.4 Population pyramid of India

8.1 Animal and vegetable protein consumption

8.2 Malnutrition and disease in South America

8.3 Illiteracy in Latin America

8.4 Rural and urban growth estimates

9.1 Transport in Bolivia

9.2 The least developed and most seriously affected countries 


\section{List of Tables}

1.1 Estimate of world population growth during the past million years

1.2 Growth of population by continents

2.1 Population density by continents

4.1 Average population density

4.2 Population/Resource types

4.3 Wealth and poverty in terms of G.N.P., 1975

5.1 The demographic situation in selected developed and developing countries

5.2 Number and percentage of world population living in towns of over 5000 population

6.1 Energy consumption for selected countries

7.1 Population growth in selected countries

7.2 Estimated percentage population increases in each continental area

7.3 Percentage of world population contained in each continental area

7.4 Population projections for A.D. 2041

8.1 Food supplies: calories and proteins per caput compared with respective requirements

8.2 Fastest growing cities in the world

8.3 Population growth of selected cities

8.4 Urban population as a percentage of total population

9.1 The least developed and most seriously affected of the developing countries

12.1 World production of selected resources over the ten-year period 1962-72 


\section{Preface}

The subject of population and resources in one form or another is widely taught. There are, indeed, already many books on the market covering either one or the other, and occasionally both, of these topics but the level, quality and price vary greatly. The aim here has been to produce a readable, well-organised, and comprehensive coverage of the subject at a reasonable price. To cover such a wide field of study in a mere 200 pages or so has demanded considerable compression, but I have given varied supporting national and regional case examples taken from all parts of the world.

The book is intended to meet the needs of A-level Geography and other sixthform courses with a population component (for example some environmental science courses); various courses, but mainly Geography and Environmental Studies, in Colleges of Education; and some study centres in Polytechnics which have broadly based curricula. It may also have some value as a teachers' source book. It has been my own experience that students beginning serious study all too often reveal little real, systematically organised knowledge of world population dynamics and distribution, and are equally uncertain about definitions of resources and population. It is hoped this book will give them some understanding of these things and, also, stimulate concern and discussion.

Perhaps I should state my viewpoint: although I have tried to be objective (I am neither an optimist nor a pessimist), a somewhat gloomy attitude towards population and environmental problems shows through the text, although as the contents reveal several chapter headings concerned with 'Problems' this attitude is more implicit than clearly stated. The text also contains many value-judgements of a general nature, though these are mostly non-controversial in their nature.

I hope the reader will find this book a clearly written, logically structured and reasonably balanced treatment of the subject, which also achieves an efficient and discriminating review of the 'highlights' of the preceding literature.

H.R. 


\section{Acknowledgements}

Grateful acknowledgement is made to the following for their kind permission to use some figures: figure 1.2 to Warren $\mathrm{S}$. Thompson and David T. Lewis, Population Problems, New York: McGraw-Hill, 1965; for figures 3.1, 3.2 and 3.3 to the late Sir L. Dudley Stamp, Our Developing World, Faber and Faver, 1960; for figure 3.4 to Paul P. Ehrlich and Anne H. Ehrlich for their figure in Population, Resources, Environment, W.H. Freeman, 2nd edn, 1972, after Preston E. Cloud Jr, 'Realities of Mineral Distribution', Texas Quarterly, Vol.II,pp.103-126, 1968; figure 4.1 reproduced from Hauser and Duncan, The Study of Population, 1959, by permission of The University of Chicago Press and Goode's World Homolosine projection, Copyright the University of Chicago Department of Geography; for figure 6.4 based upon Hugh D. Clout's map in Regional Development in Western Europe, Wiley, 1975. For most of the other figures the sources are given; the remainder are my own drawings.

Acknowledgement is also due to several publishers for their permission to use quotations: to Heinemann Educational Books Ltd, for two extended quotes from C.W. Park's, The Population Explosion, 1965; to W.H. Freeman for several quotes from Paul R. Ehrlich and Anne H. Ehrlich's Population, Resources, Environment; to Weidenfeld and Nicolson for quotations from R. Lawton in The UK Space, 1973, ed. J.W. House; to Methuen \& Co. Ltd., for several quotes from B.W. Hodder's, Economic Development in the Tropics; and to Penguin Books for three quotations from The Last Resource by Tony Loftas. 